\title{
Dolleschall János
}

\section{Epikurosz és a halálfélelem}

Az emberek többsége fél a haláltól. Ez a félelem valószínűleg abból adódik, hogy egy ismeretlen dologgal állunk szemben. Az ember általában tart mindentől, amiről nem tudja, hogy mi, így a haláltól is. Ráadásul a haláltól való rettegést még az a vallásos meggyőződés is növeli, hogy a túlvilágon a bünösökre büntetés vár. Ez azért ijesztő, mert mindenki, ha mélyen magába néz, találni fog valami "bün"-t, melyért büntetésre számíthat. Ráadásul a „moralisták” már az ókorban is rendkívül kegyetlen büntetéseket emlegettek egyes bűnök következményeként. Vegyük például Platón Államából "Er-mítoszát", melyből megtudhatjuk, hogy minden bűnért tízszeres büntetés jár. Gondoljunk csak bele, ha valakit, pl. gyomorszájon vágunk, mi ezt tízszer kapjuk vissza!

Nézzük Epikurosz milyen gyógyszert ajánl a halálfélelem ellen: „A halál számunkra semmi; a feloszlott ugyanis nem érzékel; ami pedig nem képes érzékelni, az számunkra semmi." ${ }^{11}$ Ez a kijelentés két szempontból is jelentős. Először próbáljuk meg felületesen értelmezni, mint ahogy Long is teszi a Hellenisztikus filozófiában: „Azt reméli, ha tagadja, hogy a személyiség a halál után bármilyen formában fönnmarad, akkor be tudja bizonyítani, hogy a földi életben elkövetett dolgokért járó jutalmak és büntetések rendszerébe vetett hit nem egyéb, mint merő mitológia." ${ }^{2}$ Valóban, ha ez így van, nem kell félnünk a

\footnotetext{
${ }^{1}$ Epikurosz: Küriai doxia (II.), idézi Long: Hellenisztikus filozófia, Osiris, Budapest, 1998, 71.0.

${ }^{2}$ Long: Hellenisztikus filozófia, Osiris, Budapest, 1998, 71.0.
} 
túlvilági büntetéstől. A túlvilág helyébe a semmi kerül. A semmi, pedig nem rossz, hanem egyszerüen semmilyen. Lucretius is amellett érvel, hogy ha nem létezünk, nem érhet semmilyen hatás, így nem lehet semmi kellemetlenségben részünk.

Még mielőtt tovább lépnénk, részletesebben is ki kell térnünk Lucretiusra, mert néhány ponton eltér Epikurosztól. "Semmi tehát a halál"3 kezdi Lucretius mondandóját, majd rögtön elkezd amellett érvelni, hogy nincs okunk félni tôle. Halálunk után, bármilyen katasztrófa történik is, ez nem fog minket zavarni ugyanúgy, ahogy születésünk előtt sem zavart, hiszen nem lesz öntudatunk. Ám ezután mintha kicsit szkeptikusabban kezdené el kezelni a halál kérdését:

"Ámde ha érzene is [ti. az öntudatunk] testünktől

elkülönülve,

Mint attól elvált $s$ különálló lelki tehetség,

Az sem hatna reánk, kik lélek és test anyagából

Jöttünk létre $s$ válottunk alkalmas egésszé. ${ }^{\prime 4}$

Pusztán feltevésként megjegyzi, hogy abban az esetben, ha az öntudatunk mégis túléli a test halálát, ez akkor sem probléma, mert mi, mint test és lélek vagyunk egész, tehát az öntudatunk önmagában tulajdonképpen nem is mi vagyunk. Ez a gondolatmenet további magyarázatot igényelne, ám Lucretius ehelyett újabb meglepő tézissel rukkol elő:

„Vagy ha halálon túl az idő még egyszer olyanná Változtatná is testünk anyagát, amilyen volt,

$S$ újból felcsillanna az élet fénye elöttünk,

Ez sem volna reánk már többé semmi hatással,

Meg lévén egyszer múltunk emléke szakadva. Úgy mint most sem bánt, hogy régebben kicsodák is

${ }^{3}$ Lucretius: A természetről, III. könyv, 827. sor 
Voltunk, és többé nem gondol véle az ember.

Mert ha reá gondolsz, hogy a végtelenül nagy időből Mennyi lefolyt már, és hogy az őselemekben a mozgás

Mily sokféle, egész könnyen képzelheted azt, hogy

Testünk magvai már gyakran léteztek ilyesmi

Rendben, mint amilyenben most vannak, de azért nem

Képes az ember eszével visszaidézni a múltat, Mert közben szünet állt be az életben, s valamennyi Mozgás érzés nélkül játszódott le az ürben." ${ }^{5}$

A fenti idézetben Lucretius lehetségesnek véli, hogy mi tulajdonképpen már léteztünk a születésünk előtt is. $A z$ érvelés kicsit hasonlít ahhoz, ahogy Nietzsche érvel az örök visszatérés mellett. A lényeg $a z$, hogy mivel az idő végtelen (vagy közel végtelen), és az atomok véletlenszerü kombinációja hozza létre a testeket, előfordulhat, hogy már létezett a mi testünket (és lelkünket) alkotó atomkombináció. Homályban marad, hogy Lucretius szerint ahhoz, hogy "visszatérjünk" csak az szükséges, hogy az atomok ugyanolyan formában kapcsolódjanak össze, mint korábban, vagy az is szükséges, hogy ugyanazon atomok alkossák a kombinációt. Az viszont bizonyos, ha ez így van, akkor sincs semmi okunk félni a haláltól, mert a két életünk között nem fogunk szenvedni (mert nem létezünk), az új életben pedig, már nem fogunk emlékezni az elmúltra.

Mindezek után visszatér annak a bizonyítására, hogy, ha nem létezünk, nem szenvedhetünk. Nem kell aggódnunk amiatt, hogy mit kezdenek holttestünkkel, mert már úgysem érezzük. Nem lesznek vágyaink, sem fájdalmaink. Örök békében nyugodhatunk, és nem kell valamilyen túlvilági büntetéstől szenvednünk.

De biztos, hogy aki nem hisz a túlvilágban, nem fog

${ }^{4}$ Lucretius: A természetről, III. könyv, 840-843. sor 
félni a haláltól? Biztos, hogy a semmi semmilyen? A semmi talán az unalomhoz hasonlít a legjobban. Az unalomra se mondható, hogy eredendően jó vagy rossz lenne. Vagy mégis? Ki szeret unatkozni? Az unalom nyílván nem jó, tehát rossz. És a semmi? Ki merné azt mondani a semmire, hogy jó? Ha nem létezünk, akkor viszont a semmi nem lehet rossz sem, és egyáltalán nem lehet semmilyen. Ez rendben van, de amíg létezünk, valahogy viszonyulunk a semmihez. Márpedig ez a viszonyulás csak pozitív vagy negatív lehet (ha valamihez semlegesen viszonyulunk, akkor nem viszonyulunk hozzá). Akik számára az élet nem más, mint szenvedés, lehet, hogy a semmi jó (pl. Schopenhauer). Ám az emberek nagy többsége többé-kevésbé élvezi az életet (vagy létet), és a semmit rossznak tartja. Ilyen körülmények között a semmi, mint egy rém ott áll az élet végén és rettegéssel tölt el minden pillanatot, melyben az életet élvezzük. Gondoljunk csak Don Manuel-re, Unamuno kisregényének főszereplőjére. Don Manuel egy falunak az egyetlen plébánosa. A faluban mindenki mélyen vallásos, látszólag ő is. A háttérben azonban egy sötét titok lappang. Don Manuel sem Istenben, sem a túlvilágban nem hisz. Ugyanúgy, ahogy Epikurosz meg van róla győződve, hogy a halál után a lélek megsemmisül. Vajon miért nem mondja el az igazat? Amikor Lázaro ezt a szemére veti, a következőt válaszolja: „Az igazság? Lázaro, lehet, hogy az igazság valami rettenetes, valami elviselhetetlen, valami gyilkos dolog; az egyszerü emberek nem élnék túl." ${ }^{6}$ Arról van szó, hogy az embereknek szüksége van rá, hogy higgyenek a túlvilágban. Ha megtudnák, hogy a halállal végleg kilépnek a létből, minden reményüket elvesztenék.

\footnotetext{
${ }^{5}$ Uo., 844-858. sor

${ }^{6}$ Unamuno: Don Manuel, szent vértanú, in: Öt kisregény, Nagyvilág, Budapest, 1999, 158.0.
} 
Azonban, mint már említettem, eddig felületesen elemeztük Epikuroszt, most ássuk magunkat mélyebbre agyának atomjai közé! "A halál számunkra semmi" kijelentésen van a hangsúly. A halál nincsen, nem létezik, nem avatkozik bele az életbe. Amíg élünk (egzisztálunk), addig a halál nem jön el, majd miután eljött, mi már nem egzisztálunk. Az ember egész egyszerüen nem hal meg. A halálra mindig csak, mint jövőbeni eseményre gondolhatunk. És ez miért jó? Mert mindig van reményünk rá, hogy tovább élünk, még a halálunk előtti néhány másodpercben is. Nyugodtan halhatatlannak tarthatjuk magunkat, és nem kell félnünk a haláltól, mert, ha még élünk nyugodtan bízhatunk abban, hogy a következő pillanatban, órában, évben is élni fogunk. A haldokló még eltervezheti, hogy másnap mit fog csinálni, reménykedhet a folytatásban. Ha viszont meghal, elillan a remény, de ő ezt már nem éli meg. Mivel az ember képtelen megélni a halált, így a halál eliminálódik. Ám a továbbélés reménye mindig megmarad. Kicsit elrugaszkodva Epikurosztól, még azt is mondhatjuk, hogy, ha valaki teljesen biztos rövidesen bekövetkező halálában még mindig bízhat a túlvilági életben. Számára a túlvilág valóban létezni fog, hiszen soha nem döbbenhet rá, hogy nem létezik. Ezért fontos, hogy Don Manuel ateista meggyőződése ellenére Isten és a túlvilág létét prédikálja az embereknek.

Van egy tényezője az epikureus halálfelfogásnak, amivel ritkán és keveset foglalkoznak a kommentárok. Az eddigiekből kiderült, hogy az ember miként viszonyulhat saját halálához. De mi a helyzet a másik ember halálával? Például egy barát halálával, hiszen az epikureusoknál a barátság a legnagyobb etikai érték. "Azt, amit megéltünk, még a minket majd elragadó halál sem ragadhatja el tőlünk: ezek bizony halhatatlanok, mondja Epikurosz, nem azért, mert nem halunk meg, hanem azért, mert a halál sem 
törölheti el azt, amit megéltünk, azt, amit mulandóan, de végérvényesen megéltünk." ${ }^{7}$ mondja Comte-Sponville Epikuroszt idézve. Nem a múlt az, amit a halál megsemmisít, hanem a jövő. A múlt mindig megmarad, mert már megéltük és nem vonhatjuk vissza. Mégis van hát az emberben valami, ami halhatatlan. Ha meghalunk, egy barátunk vagy ismerősünk mindig visszaidézheti, amit együtt átéltünk, s így halhatatlanná válunk. Ezek az emlékek sosem csak $x$ vagy y barátunk emlékei, hanem egyben a mieink is, hiszen $\mathrm{mi}$ is szereplünk benne. A halállal elvész a lélek, de az emlék megmarad, elvész a jövő, de a múlt örök.

Ez eddigiek után érdemes még szót ejteni az epikuroszi halálfelfogás hatásairól. Ennek több eleme is megjelenik későbbi filozófusoknál, főként az egzisztencialistáknál ( $\mathrm{pl}$. Unamuno) ${ }^{8}$, vagy Wittgenstein-nél. És Wittgenstein az, akiről most bővebben szólnék, mivel halálfelfogása oly hasonló epikuroszéhoz, hogy akár neoepikureusnak is mondhatjuk. A halálról vallott nézeteit elsősorban a Logikai-filozófiai értekezésben fejti ki.

"Mint ahogy a halál bekövetkezésével sem változik meg a világ, hanem véget ér." ${ }^{\prime 9}$ Ezzel a mondattal kezdi Wittgenstein a halálra vonatkozó eszmefuttatását. Ha meghalunk számunkra véget ér a világ, tehát a halál után nem kerülünk egy másik jobb vagy rosszabb világba. Epikurosznál is hasonló a helyzet, mint ahogy már fentebb láttuk, nincs semmilyen más világ, ahol az élet folytatódhatna. De a wittgenstein-i kijelentésből $a z$ is levonható, hogy teljesen mindegy, hogy úgy halunk meg, hogy mások túlélnek bennünket, vagy úgy, hogy az egész

\footnotetext{
7 Comte-Sponville: Kis könyv a nagy erényekröl, Osiris, Budapest, 2001, 169.0.

${ }^{8}$ Az egzisztencialisták halálfelfogásáról bővebben lásd: Csejtei Dezső: Filozófiai metszetek a halálról, Pallas-Attraktor, Budapest, 2002

${ }^{9}$ Wittgenstein: Logikai-filozófiai értekezés, Akadémia, Budapest, 1989, 88.o.
} 
világ véget ér mikor meghalunk. Vagyis, ha egy természeti katasztrófa miatt kihal az emberiség, az semmivel sem rosszabb, mintha csak én halnék meg, hiszen a világ számomra így is úgy is véget ér. Ám Epikurosz ezzel nem értene egyet. Nem, mert nála nagy szerepe van a hermeneutikai halhatatlanságnak, annak, hogy a régi idők emléke fennmaradhasson valaki emlékezetében. Azzal viszont egyet értene, hogy "a halál nem eseménye az életnek. A halált az ember nem éli át. ${ }^{10}$ Ez tulajdonképpen azt mondja, amit már fent említettem, amíg élünk nincs jelen a halál, amikor a halál eljő, akkor már nem leszünk. Nem kell félnünk a haláltól, mert soha sem fogunk találkozni vele, nem éljük át.

Wittgenstein-nél is van bizonyos fajta örökélet vagy halhatatlanság koncepció, de ez nem egyezik meg azzal, amit Epikurosz kifejtett az emlékről, ám egy olyan ötlet, mely akár neki is eszébe juthatott volna. „Ha az örökkévalóságon nem végtelen időtartamot, hanem időtlenséget értünk, úgy örökké él az, aki a jelenben él." ${ }^{11}$ Éljünk a jelenben és az életünk örök lesz. Ki tudjuk küszöbölni a jövőt a jelennel. Ez a kijelentés, habár Epikurosz nem fejti ki expliciten, mégis ott bujkál az epikureus felfogásban. Az epikureus etikából, $a z$ élet élvezetéből, a hedonizmusból következik, hogy a jelenben kell élni. "Szakítsd le a napot”, ahogy Horatius mondta. Mind Wittgenstein-nél, mind az epikureusoknál hallatlan szerepe van a jelennek, etikájuk egyik lényegi pontja a pillanat élvezete, mert ezzel még az örök élet is lehetővé válik. „Életünk éppúgy vég nélküli, ahogy látóterünk határ nélküli"12 füzi még hozzá Wittgenstein. Hiába tekintünk a

\footnotetext{
${ }^{10}$ Wittgenstein: Logikai-filozófiai értekezés, Akadémiai, Budapest, 1989, 88.0.

${ }^{11}$ Uo.

12 Uo.
} 
jövőbe, a halált nem pillanthatjuk meg, mert ilyen esemény nincs. Csak az életünkre tekinthetünk elöre, abban viszont nem szerepel a halál. Ráadásul, ha a jelenben élünk, egyébként sem kell a jövőre gondolnunk.

Wittgenstein még elmondja, hogy a lélek halhatatlansága, mint az időbeni végtelen élet nem bizonyítható, és ha az lenne, akkor se oldaná meg a világ megismerhetőségének problémáját. Ebbe viszont már ne menjünk bele, hiszen csak a halálról és nem a megismerésről kívántunk beszélni.

Végül tekintsük át az epikureus halálfelfogás föbb momentumait! Először is megtudtuk, hogy a halállal elvész a lélek, ezért nem kell attól tartanunk, hogy a pokolba kerülünk. Lucretius ehhez még azt is hozzáfüzte, hogy lehetséges a visszatérés, de ez nem változtat lényegében semmin, mert az előző életünkre nem fogunk emlékezni, a két életünk között, pedig nem létezünk. Másodszor a halál mivel "nem eseménye az életnek", nem megélhető, ezért nem kell attól tartanunk, hogy valaha is találkozunk vele. Mindig remélhetjük, hogy még nem jön el, ha pedig eljött, mi már nem fogjuk tudni. Harmadszor kijelenthetjük azt is, hogy létezik bizonyos fajta halhatatlanság. Hiszen egyrészt a múlt, az emlékek mindig megmaradnak, ezeket senki sem veheti el tőlünk. Másrészt, ha a pillanat örömeit élvezzük, képesek lehetünk a jelenben élni, és mivel nem látjuk a halált, mint a jövőt, ezért örökké élünk. A lényeg tehát $a z$, hogy a halál semmi, ezért "sose halunk meg"! 